\title{
Hydrogen Sulfide in Hypertension and Kidney Disease of Developmental Origins
}

\author{
Chien-Ning Hsu ${ }^{1}$ and You-Lin Tain ${ }^{2,3, *(\mathbb{D})}$ \\ 1 Department of Pharmacy, Kaohsiung Chang Gung Memorial Hospital, Kaohsiung 833, Taiwan; \\ chien_ning_hsu@hotmail.com \\ 2 Departments of Pediatrics, Kaohsiung Chang Gung Memorial Hospital and Chang Gung University \\ College of Medicine, Kaohsiung 833, Taiwan \\ 3 Institute for Translational Research in Biomedicine, Kaohsiung Chang Gung Memorial Hospital and \\ Chang Gung University College of Medicine, Kaohsiung 833, Taiwan \\ * Correspondence: tainyl@hotmail.com; Tel.: +886-975-056-995; Fax: +886-7733-8009
}

Received: 12 April 2018; Accepted: 9 May 2018; Published: 11 May 2018

\begin{abstract}
Adverse environments occurring during kidney development may produce long-term programming effects, namely renal programming, to create increased vulnerability to the development of later-life hypertension and kidney disease. Conversely, reprogramming is a strategy aimed at reversing the programming processes in early life, even before the onset of clinical symptoms, which may counter the rising epidemic of hypertension and kidney disease. Hydrogen sulfide $\left(\mathrm{H}_{2} \mathrm{~S}\right)$, the third gasotransmitter, plays a key role in blood pressure regulation and renal physiology. This review will first present the role of $\mathrm{H}_{2} \mathrm{~S}$ in the renal system and provide evidence for the links between $\mathrm{H}_{2} \mathrm{~S}$ signaling and the underlying mechanisms of renal programming, including the renin-angiotensin system, oxidative stress, nutrient-sensing signals, sodium transporters, and epigenetic regulation. This will be followed by potential $\mathrm{H}_{2} \mathrm{~S}$ treatment modalities that may serve as reprogramming strategies to prevent hypertension and kidney disease of developmental origins. These $\mathrm{H}_{2} \mathrm{~S}$ treatment modalities include precursors for $\mathrm{H}_{2} \mathrm{~S}$ synthesis, $\mathrm{H}_{2} \mathrm{~S}$ donors, and natural plant-derived compounds. Despite emerging evidence from experimental studies in support of reprogramming strategies targeting the $\mathrm{H}_{2} \mathrm{~S}$ signaling pathway to protect against hypertension and kidney disease of developmental origins, these results need further clinical translation.
\end{abstract}

Keywords: developmental origins of health and disease (DOHaD); hydrogen sulfide; hypertension; kidney disease; nitric oxide; nutrient-sensing signals; oxidative stress; renin-angiotensin system

\section{DOHaD Concept: Hypertension and Kidney Disease of Developmental Origins}

One in three adults worldwide has high blood pressure (BP). The prevalence of hypertension is even higher among patients with kidney disease. Conversely, kidney disease is the most common form of secondary hypertension. In addition to sharing many common risk factors, hypertension and kidney disease could be the cause and consequence of each other. Hypertension as well as kidney disease, when found early, can be treated to prevent more related disorders and serious complications. Environmental factors in fetal and infantile life can be important early origins of adult disorders due to fetal programming that permanently shapes the body's morphology and function and contributes to adult disease. This idea is framed as the developmental origins of health and disease (DOHaD) [1]. Notably, following the concept of $\mathrm{DOHaD}$, both of these disorders may originate from adverse early-life environmental insults [2-4].

Kidneys play a decisive role in blood pressure (BP) regulation. Adverse environments occurring during nephrogenesis may produce long-term programming effects on the structure and/or function 
of the kidney, formally known as renal programming [5], which may increase the vulnerability to developing hypertension and kidney disease in adulthood. Conversely, reprogramming, a strategy aimed at reversing the initial programming processes, is afforded by the $\mathrm{DOHaD}$ concept to shift therapeutic interventions from adulthood to early life, even before the onset of clinical symptoms [6]. A growing body of evidence suggests that hydrogen sulfide $\left(\mathrm{H}_{2} \mathrm{~S}\right)$ plays a crucial role in the normal physiology and pathogenesis of many disorders, and many therapeutic targets exist for $\mathrm{H}_{2} \mathrm{~S}$ therapy $[7,8]$. Based on the two aspects of the DOHaD concept, this review will first present the evidence for the programming mechanisms that may lead to hypertension and kidney disease of developmental origins, with a focus on the kidney. This will be followed by potential pharmacological interventions targeting $\mathrm{H}_{2} \mathrm{~S}$ signaling that may serve as a reprogramming strategy to counter the growing epidemic of hypertension and kidney disease.

\section{Hydrogen Sulfide in Renal System}

\section{1. $\mathrm{H}_{2} \mathrm{~S}$ Production and Biological Function}

$\mathrm{H}_{2} \mathrm{~S}$, the third gasotransmitter, next to nitric oxide (NO) and carbon monoxide $(\mathrm{CO})$, plays a key role in BP control and renal physiology [7-9]. The production of $\mathrm{H}_{2} \mathrm{~S}$ can occur via two pathways, enzymatic and nonenzymatic. Enzymatic synthesis of $\mathrm{H}_{2} \mathrm{~S}$ from L-cysteine occurs through three enzymes, cystathionine $\beta$-synthase (CBS), cystathionine $\gamma$-lyase (CSE), and 3-mercaptopyruvate sulphurtransferase (3MST), which work together with cysteine amino transferase (CAT) [7]. L-cysteine serves as a substrate for both CBS and CSE to form $\mathrm{H}_{2} \mathrm{~S}$. CBS and CSE can generate $\mathrm{H}_{2} \mathrm{~S}$ using many different substrates. CBS catalyzes homocysteine and serine to generate cystathionine. CSE catalyzes L-cysteine to produce pyruvate, $\mathrm{H}_{2} \mathrm{~S}$, and ammonia. CSE also breaks down cystathionine into L-cysteine, $\alpha$-ketobutyrate, and ammonia. In an alternative pathway, CAT and D-amino acid oxidase (DAO) provide 3-mercaptopyruvate (3MP) for 3MST to produce $\mathrm{H}_{2} \mathrm{~S}$. Additionally, D-cysteine can be metabolized by DAO to generate $\mathrm{H}_{2} \mathrm{~S}$ in the kidney [10]. In the presence of $\alpha$-ketoglutarate, CAT metabolizes L-cysteine to form 3MP, whereas DAO produces 3MP from D-cysteine. All of these $\mathrm{H}_{2} \mathrm{~S}$-generating enzymes are expressed abundantly in the kidney. Interestingly, renal production of $\mathrm{H}_{2} \mathrm{~S}$ from D-cysteine is approximately 80 times greater than that from L-cysteine [10]. Alternatively, nonenzymatic production of $\mathrm{H}_{2} \mathrm{~S}$ occurs through glucose, glutathione, inorganic and organic polysulfides, and elemental sulfur. The biochemical pathways related to the $\mathrm{H}_{2} \mathrm{~S}$ synthesis are illustrated in Figure 1. 


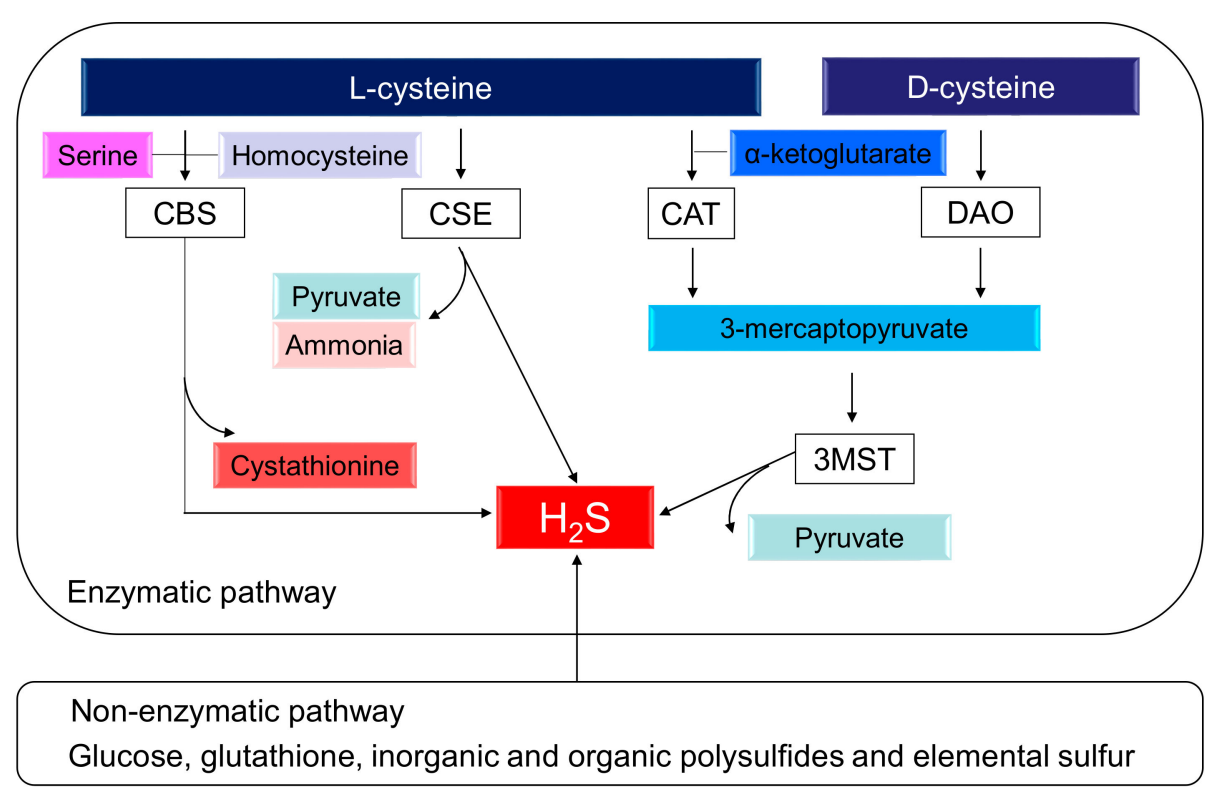

Figure 1. Schematic representation of enzymatic and nonenzymatic $\mathrm{H}_{2} \mathrm{~S}$ synthesis pathways. Cystathionine $\beta$-synthase (CBS) catalyzes homocysteine and serine to produce $\mathrm{H}_{2} \mathrm{~S}$ and L-cystathionine. Cystathionine $\gamma$-lyase (CSE) catalyzes L-cysteine to generate $\mathrm{H}_{2} \mathrm{~S}$, pyruvate, and ammonia. 3-Mercaptopyruvate sulfurtransferase (3MST) produces $\mathrm{H}_{2} \mathrm{~S}$ from 3-mercaptopyruvate (3MP), which is generated by cysteine aminotransferase (CAT) and D-amino acid oxidase (DAO) from L-cysteine and D-cysteine, respectively. In addition to enzymatic synthesis pathways, endogenous production of $\mathrm{H}_{2} \mathrm{~S}$ can also occur through other nonenzymatic processes.

$\mathrm{H}_{2} \mathrm{~S}$ has diverse and widespread biological functions, including vasodilatation, mitochondria bioenergetics, metabolic modulation, renal excretory function, angiogenesis, anti-inflammation, antioxidant, and antiapoptosis [7-9]. Until recently, the biological mechanisms of $\mathrm{H}_{2} \mathrm{~S}$ signaling have been incompletely understood. One pathway for $\mathrm{H}_{2} \mathrm{~S}$ signaling is through protein sulfhydration by the formation of a persulfide bond to the reactive cysteine residues of target proteins [11]. There is some evidence that $\mathrm{H}_{2} \mathrm{~S}$ signaling regulates physiological processes via sulfhydration, but the mechanisms involved are still not well characterized.

\subsection{Antihypertensive and Renoprotective Effects of $\mathrm{H}_{2} \mathrm{~S}$}

In the spontaneously hypertensive rat (SHR), a commonly used genetic hypertensive model, $\mathrm{H}_{2} \mathrm{~S}$ deficiency appears prior to the development of hypertension, whereas the administration of exogenous $\mathrm{H}_{2} \mathrm{~S}$ donor (NaHS) protects SHRs against hypertension [12]. The contribution of $\mathrm{H}_{2} \mathrm{~S}$ deficiency in hypertension has been studied in other models of hypertension, including the renovascular hypertensive model [13], NO-deficient rats [14], and Dahl salt-sensitive rats [15]. In agreement with these studies, CSE knockout mice have also been found to have reduced levels of $\mathrm{H}_{2} \mathrm{~S}$ and hypertension [16]. However, this could not be confirmed in another type of CSE knockout mouse model on a different genetic background [17]. $\mathrm{H}_{2} \mathrm{~S}$ signaling deficiencies have also been associated with various kidney diseases, such as renal ischemia/reperfusion injury, obstructive nephropathy, diabetic nephropathy, hypertensive nephropathy, and the 5/6 nephrectomy rat model of chronic kidney disease. These models have been reviewed elsewhere $[18,19]$. Conversely, a number of recent studies stress the protective role of exogenous and endogenous $\mathrm{H}_{2} \mathrm{~S}$ on hypertension and kidney disease, and this has also been reviewed elsewhere [20-22]. However, limited information is available on whether these beneficial mechanisms could be programmed in response to early-life insults in the kidney, to reduce the vulnerability to developing later hypertension and kidney disease. 


\section{Common Mechanisms Link $\mathrm{H}_{2} \mathrm{~S}$ to Renal Programming}

Though a variety of organ systems can be programmed in response to early-life adverse environmental insults, renal programming is considered crucial in the development of hypertension and kidney disease [4-6]. Despite the diversity of early-life insults, emerging evidence indicates that there may be common mechanisms underlying renal programming which lead to the pathogenesis of hypertension and kidney disease of developmental origins. Though the common pathogenic mechanisms are still inconclusive, animal models have provided insight on particular pathways including the renin-angiotensin system (RAS), oxidative stress, nutrient-sensing signals, dysregulation of sodium transporters, and epigenetic regulation [2-6,23]. Notably, these extensive experimental animal studies have demonstrated interplay between $\mathrm{H}_{2} \mathrm{~S}$ and the abovementioned mechanisms. Each of these examples will be discussed in turn.

\subsection{Renin-Angiotensin System}

The RAS is a well-known hormonal cascade controlling BP and kidney development [24,25]. Currently, there are two main axes of the RAS: (1) the angiotensin-converting enzyme (ACE)-angiotensin (Ang) II-angiotensin type 1 receptor (AT1R) classical axis and (2) the ACE2-angiotensin (1-7)-Mas receptor axis [24]. Both axes have been examined in relation to their impacts on fetal programming [26,27]. There is a biphasic response with reduced classical RAS expression at birth, which becomes normalized with age [5]. Under pathophysiological scenarios where this normalization overcompensates, early-life renal programming subsequently activates the classical RAS, resulting in hypertension and kidney disease development in later life [5]. Conversely, early blockade of the classical RAS has been shown to prevent the development of hypertension [28-30]. These observations support the view that RAS may be an underlying mechanism involved in renal programming and the development of hypertension and kidney disease. Decreased $\mathrm{H}_{2} \mathrm{~S}$ levels or downregulation of $\mathrm{H}_{2} \mathrm{~S}$-generating enzymes have been found in some hypertensive models with activation of the RAS [31,32]. Exogeneous $\mathrm{H}_{2} \mathrm{~S}$ administration has been shown to suppress renin release [32], downregulate renal mRNA expression of Ren, Atp6ap2, Agt, Ace, and Agtr1a [33], and decrease protein expression of AT1R [34], resulting in protection from hypertension. Nevertheless, the detailed mechanisms underlying the modulation of RAS by $\mathrm{H}_{2} \mathrm{~S}$ contributing to the protection of programmed kidney disease need to be further investigated.

\subsection{Oxidative Stress}

The development of the embryo occurs in a relatively low-oxygen environment, and the developing fetus is highly vulnerable to oxidant injury due to its low antioxidant capacity [35]. Oxidative stress is an oxidative shift characterized by an imbalance between oxidants (e.g., reactive oxygen species (ROS) or reactive nitrogen species (RNS)) and antioxidants in favor of oxidants. A number of recent studies support the importance of oxidative stress in relation to programmed hypertension and kidney disease in different models, including pre-eclampsia, caloric restriction, maternal diabetes, prenatal dexamethasone exposure, high fructose intake, maternal smoking, and low-protein diet $[6,36]$. On the contrary, some reprogramming strategies have aimed at influencing the balance of NO-ROS to reduce oxidative stress and thus prevent hypertension and kidney disease of developmental origins [36]. $\mathrm{H}_{2} \mathrm{~S}$ is a Janus-faced molecule that acts either as a pro-oxidant or antioxidant [37]. It can interact with ROS or RNS to generate free radicals. Conversely, $\mathrm{H}_{2} \mathrm{~S}$ has an antioxidant property, by which it modulates the concentration of glutathione, an important intracellular thiolic antioxidant, and acts as a free radical scavenger [38]. Like NO, $\mathrm{H}_{2} \mathrm{~S}$ causes vasodilatation and there is crosstalk between these two molecules to regulate BP $[7,8]$. Thus, these findings suggest that suppression of oxidative stress may contribute to antihypertensive effects of $\mathrm{H}_{2} \mathrm{~S}$. However, whether the antioxidative ability of $\mathrm{H}_{2} \mathrm{~S}$ in itself is important in reducing the BP in concert with other BP-lowering actions remain to be clarified. 


\subsection{Nutrient-Sensing Signals}

Imbalanced maternal nutrition and metabolic insults can disturb nutrient-sensing signals, which play a key role in fetal metabolism and development, resulting in renal programming and developmental hypertension $[39,40]$. A number of nutrient-sensing signaling pathways exist in the kidney, including cyclic adenosine monophosphate (AMP)-activated protein kinase (AMPK), silent information regulator transcript (SIRT), peroxisome proliferator-activated receptors (PPARs), and PPAR $\gamma$ coactivator- $1 \alpha$ (PGC-1 $\alpha$ ) [41]. Early-life nutritional insults can drive nutrient-sensing signals (e.g., AMPK, SIRT1, and PGC- $1 \alpha$ ) to regulate PPARs and their target genes, thereby promoting programmed hypertension and kidney disease [42]. AMPK, SIRT1, and PGC- $1 \alpha$ can also promote autophagy, a lysosome-mediated degradation process for damaged cellular constituents. Since dysregulation of autophagy causes abnormal mitochondrial function and increased oxidative stress [43], early interventions by AMPK activators or PPAR modulators have been examined as reprogramming strategies in $\mathrm{DOHaD}$ research $[42,44]$. It is noteworthy that one of the beneficial effects of $\mathrm{H}_{2} \mathrm{~S}$ is the activation of AMPK and promotion of autophagy [45]. Further efforts are required to advance our understanding of the long-term programming effects of $\mathrm{H}_{2} \mathrm{~S}$ on nutrient-sensing signals and their relationships to hypertension and developmental kidney disease.

\subsection{Sodium Transporters}

Fetal programming induced by early-life environmental insults that contribute to the development of hypertension is related to enhanced sodium reabsorption attributed to increased expression of sodium transporters [4]. These insults include prenatal glucocorticoid exposure [46,47], maternal low-protein diet [48], maternal high-fat diet [49], and maternal exposure to continuous light [50]. Several sodium transporters have been identified in these processes, including the $\mathrm{Na}-\mathrm{K}-2 \mathrm{Cl}$ cotransporter (NKCC2), $\mathrm{Na}^{+} / \mathrm{Cl}^{-}$cotransporter (NCC), type 3 sodium hydrogen exchanger (NHE3), and the $\mathrm{Na}^{+} / \mathrm{K}^{+}$ATPase $\alpha 1$ subunit (NaKATPase). In addition to prenatal insults, our previous study has shown that a maternal high-fructose diet plus postnatal high-salt diet increased renal levels of NKCC2, NHE3, and NCC in a two-hit model of programmed hypertension [51]. Therefore, regardless of whether the insults are prenatal or postnatal, the dysregulation of sodium transporters resulting in inappropriate sodium reabsorption could increase the vulnerability to adult hypertension and kidney disease. Notably, an exogenous $\mathrm{H}_{2} \mathrm{~S}$ donor (NaHS) has been reported to inhibit expression and/or activity of several sodium transporters, which may account for its protective effects on renal function and hypertension [52,53]. Nevertheless, there remains a lack of definitive data on how $\mathrm{H}_{2} \mathrm{~S}$ affects sodium transporters from animal models of programmed hypertension and kidney disease. It will be of great value to reveal the reprogramming effect of $\mathrm{H}_{2} \mathrm{~S}$ on sodium transporters in different models of programmed hypertension and kidney disease.

\subsection{Epigenetic Regulation}

Epigenetic regulation such as histone modifications, DNA methylation, and noncoding RNAs are involved in mediating the effects of early-life environmental influences on later-life health [54]. Epigenetics refers to alterations in gene expression that are not explained by changes in the DNA sequence. Until recently, little was known about the role of epigenetics in renal programming. A previous report has shown that maternal folic acid supplementation did not alter global DNA methylation in the offspring's kidney [55]. Another study demonstrated that renal microRNA altered the protein restriction model of fetal programming [56]. Additionally, only a few studies using high-throughput DNA sequencing technologies report that different early-life insults permanently alter the renal transcriptome expression profile in rat offspring [40,57]. Conversely, emerging evidence support the idea that $\mathrm{H}_{2} \mathrm{~S}$ has epigenetic effects by mediating DNA methylation [34], histone deacetylase (HDAC) [58], and microRNA expression [59]. These findings suggest that epigenetic regulation may be an important link between $\mathrm{H}_{2} \mathrm{~S}$ signaling and renal programming. 
All of these observations demonstrate a close link between $\mathrm{H}_{2} \mathrm{~S}$ and other important mechanisms involved in renal programming (Figure 2). Despite emerging evidence indicating crosstalk between $\mathrm{H}_{2} \mathrm{~S}$ and particular mechanisms underlying programmed processes, we are still far from the conclusion that $\mathrm{H}_{2} \mathrm{~S}$ may play a central role in mediating other mechanisms leading to hypertension and developmental kidney disease.

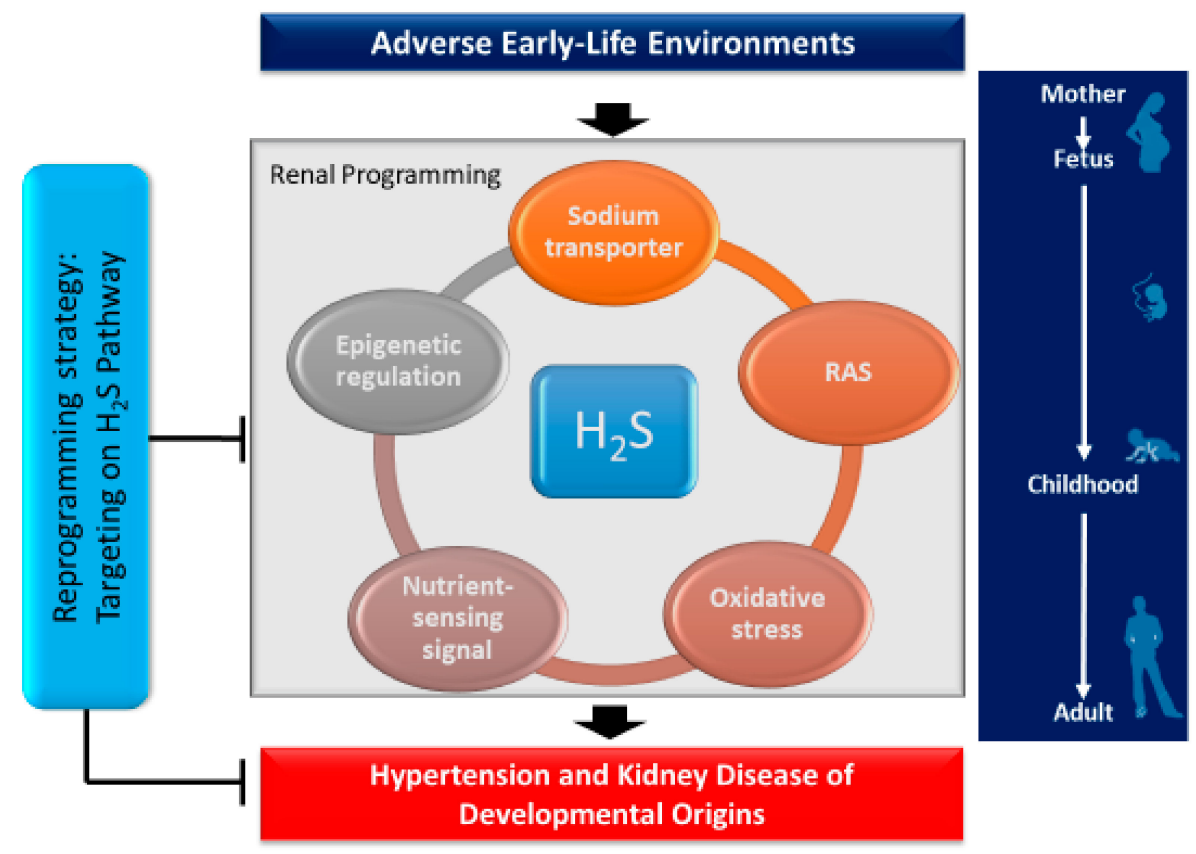

Figure 2. Schema outlining the potential role of $\mathrm{H}_{2} \mathrm{~S}$ on mediating other mechanisms in the kidney leading to hypertension and developmental kidney disease in response to a variety of early-life insults. Targeting the $\mathrm{H}_{2} \mathrm{~S}$ pathway could be a reprogramming strategy for programmed hypertension and kidney disease to reduce the lifetime burden by early intervention.

\section{Reprogramming Strategy Targeting the $\mathrm{H}_{2} \mathrm{~S}$ Signaling Pathway}

Although excess $\mathrm{H}_{2} \mathrm{~S}$ may contribute to some diseases, the application of $\mathrm{H}_{2} \mathrm{~S}$ treatment modalities to increase $\mathrm{H}_{2} \mathrm{~S}$ signaling attract the most attention [60]. As mentioned earlier, the protective effects of $\mathrm{H}_{2} \mathrm{~S}$ signaling have been demonstrated in many disorders, including hypertension and kidney disease. Therefore, the $\mathrm{H}_{2} \mathrm{~S}$ treatments presented here focus on approaches aimed to increase $\mathrm{H}_{2} \mathrm{~S}$ signaling. Currently, available $\mathrm{H}_{2} \mathrm{~S}$ treatment modalities include precursors for $\mathrm{H}_{2} \mathrm{~S}$ synthesis, $\mathrm{H}_{2} \mathrm{~S}$ donors, and natural plant-derived compounds. L-cysteine, N-acetylcysteine (NAC), and D-cysteine are precursors for endogenous $\mathrm{H}_{2} \mathrm{~S}$ synthesis. $\mathrm{H}_{2} \mathrm{~S}$ donors, including donor molecules and $\mathrm{H}_{2} \mathrm{~S}$-releasing drugs, can be divided into three types: inorganic sulfide salts (e.g., NaHS), organic compounds (e.g., GYY4137), and agonists of $\mathrm{H}_{2} \mathrm{~S}$-synthesized enzymes [60,61]. Additionally, garlic-derived polysulfides are considered to be an $\mathrm{H}_{2} \mathrm{~S}$ treatment modality as they can stimulate the production of $\mathrm{H}_{2} \mathrm{~S}$ [61].

Here, we summarize studies which document reprogramming in animal models of hypertension and kidney disease, focusing on interventions aimed at the $\mathrm{H}_{2} \mathrm{~S}$ signaling pathway. Of note, pharmacotherapies will be narrowly restricted to key periods during early development. These $\mathrm{H}_{2} \mathrm{~S}$ treatment modalities are listed in Table 1 [62-68]. This list is by no means complete and is expected to grow rapidly as the field of $\mathrm{DOHaD}$ research flourishes. 
Table 1. Reprogramming strategy targeted on $\mathrm{H}_{2} \mathrm{~S}$ signaling in models of programmed hypertension and kidney disease.

\begin{tabular}{|c|c|c|c|c|c|}
\hline Animal Models & Gender/Species & $\begin{array}{c}\text { Age at } \\
\text { Evaluation }\end{array}$ & $\begin{array}{l}\text { Dose and Period } \\
\text { of Treatment }\end{array}$ & $\begin{array}{c}\text { Reprogramming } \\
\text { Effects }\end{array}$ & Ref. \\
\hline \multicolumn{6}{|c|}{ Precursors for endogenous $\mathrm{H}_{2} \mathrm{~S}$ synthesis } \\
\hline High-salt SHR ${ }^{1}$ & Male SHR & 12 weeks & $\begin{array}{l}\text { L-cysteine }\left(8 \mathrm{mmol} \mathrm{kg}{ }^{-1}\right. \\
\text { body weight/day) from } 4 \\
\text { to } 6 \text { weeks of age }\end{array}$ & $\begin{array}{l}\text { Prevented hypertension; } \\
\text { prevented renal injury }\end{array}$ & [62] \\
\hline High-salt SHR & Male SHR & 12 weeks & $\begin{array}{l}\mathrm{D} \text {-cysteine }\left(8 \mathrm{mmol} \mathrm{kg} \mathrm{kg}^{-1}\right. \\
\text { body weight/day) from } 4 \\
\text { to } 6 \text { weeks of age }\end{array}$ & $\begin{array}{l}\text { Prevented hypertension; } \\
\text { prevented renal injury }\end{array}$ & [62] \\
\hline SHR & Male SHR & 12 weeks & $\begin{array}{c}2 \% \text { NAC }^{2} \text { in drinking } \\
\text { water from } 4 \text { to } 12 \text { weeks } \\
\text { of age }\end{array}$ & Prevented hypertension & [63] \\
\hline $\begin{array}{l}\text { Prenatal dexamethasone and } \\
\text { postnatal high-fat diet }\end{array}$ & Male $\mathrm{SD}^{3}$ rats & 12 weeks & $\begin{array}{l}1 \% \text { NAC in drinking } \\
\text { water during pregnancy } \\
\text { and lactation }\end{array}$ & Prevented hypertension & [64] \\
\hline $\begin{array}{l}\text { Suramin-induced } \\
\text { pre-eclampsia }\end{array}$ & Male SD rats & 12 weeks & $\begin{array}{l}1 \% \text { NAC in drinking } \\
\text { water during pregnancy } \\
\text { and lactation }\end{array}$ & Prevented hypertension & [65] \\
\hline $\begin{array}{c}\mathrm{N}^{\mathrm{G}} \text {-nitro-L-arginine-methyl } \\
\text { ester (L-NAME)-induced } \\
\text { pre-eclampsia }\end{array}$ & Male SD rats & 12 weeks & $\begin{array}{c}1 \% \text { NAC in drinking } \\
\text { water during pregnancy } \\
\text { and lactation }\end{array}$ & Prevented hypertension & [66] \\
\hline Maternal nicotine exposure & Male SD rats & 8 months & $\begin{array}{l}\text { NAC }(500 \mathrm{mg} / \mathrm{kg} / \text { day }) \text { in } \\
\text { drinking water from } \\
\text { gestational day } 4 \text { to } \\
\text { postnatal day } 10\end{array}$ & Prevented hypertension & [67] \\
\hline \multicolumn{6}{|l|}{$\mathrm{H}_{2} \mathrm{~S}$ donors } \\
\hline SHR & Male SHR & 12 weeks & $\begin{array}{c}\mathrm{NaHS}(14 \mu \mathrm{mol} / \mathrm{kg} / \text { day }) \\
\text { daily intraperitoneal } \\
\text { injection from } 4 \text { to } 8 \\
\text { weeks of age }\end{array}$ & Prevented hypertension & [33] \\
\hline
\end{tabular}

\subsection{Precursors for $\mathrm{H}_{2} \mathrm{~S}$ Synthesis}

L-cysteine supplementation is widely used to create endogenous $\mathrm{H}_{2} \mathrm{~S}$ in experimental studies. L-cysteine has been known to lower BP directly or through its storage form, glutathione, by decreasing oxidative stress, improving insulin resistance and glucose metabolism, and modulating NO [68]. $\mathrm{N}$-acetylcysteine (NAC), a stable cysteine analogue, has been reported to prevent hypertension in experimental and human studies [68,69], which supports this idea. However, L-cysteine is not a good $\mathrm{H}_{2} \mathrm{~S}$ precursor due to its multiple metabolic fates. Indeed, the reported antihypertensive and renoprotective effects may not be directly related to $\mathrm{H}_{2} \mathrm{~S}$ signaling. Another $\mathrm{H}_{2} \mathrm{~S}$ precursor, D-cysteine, is nutritionally antagonistic [70]; therefore, the antihypertensive effect of D-cysteine supplementation has received less attention. There is only one report demonstrating that D-cysteine supplementation protects the mouse kidney against ischemia/reperfusion injury [71].

So far, very few studies have addressed DOHaD research to explore the protective role of $\mathrm{H}_{2} \mathrm{~S}$ precursors in the kidney in response to a variety of early-life insults. We first showed that early supplementation of D- or L-cysteine between 4 and 6 weeks of age (i.e., prehypertensive stage) can protect SHRs against high-salt-enhanced elevation of BP and kidney injury [62]. Although a previous report has shown that the D-cysteine pathway is 80 -fold greater in $\mathrm{H}_{2} \mathrm{~S}$-producing activity in the kidney compared to the L-cysteine pathway [71], our data revealed that the protective effects on $\mathrm{BP}$ are similar. Correspondingly, early supplementation of NAC starting at four weeks of age has been reported to prevent hypertension in SHRs [63]. As such, the reprogramming effects of early NAC therapy on the protection of programmed hypertension have been reported in several animal models, including prenatal dexamethasone and postnatal high-fat diet [64], suramin-induced pre-eclampsia [65], $\mathrm{N}^{\mathrm{G}}$-nitro-L-arginine-methyl-ester (L-NAME)-induced pre-eclampsia [66], and maternal nicotine exposure [67]. Despite the reprogramming effects of several $\mathrm{H}_{2} \mathrm{~S}$ precursors in response to early-life 
insults that have been studied in experimental animal models, there remains a lack of data regarding their clinical translation.

\section{2. $\mathrm{H}_{2} \mathrm{~S}$ Donors}

In most studies, inorganic sulfide salts such as sodium hydrosulfide (NaHS) and sodium sulfide $\left(\mathrm{Na}_{2} \mathrm{~S}\right)$ are used as $\mathrm{H}_{2} \mathrm{~S}$ donors to generate exogenous $\mathrm{H}_{2} \mathrm{~S}$ [60]. NaHS has been reported to be protective in various hypertensive models, including SHR [72], Ang II-infused mice [31], NO-deficient rats [14], and Dahl salt-sensitive rats [15]. Additionally, the protective effects of exogenous $\mathrm{H}_{2} \mathrm{~S}$ derived from inorganic sulfide salts in different experimental models of kidney disease have been reviewed elsewhere [21,22]. However, inorganic sulfide salts induce a rapid but short-lived increase of $\mathrm{H}_{2} \mathrm{~S}$ to supraphysiological concentrations [73]. To overcome this limitation, several organic slow-releasing $\mathrm{H}_{2} \mathrm{~S}$ compounds have been synthesized [74]. Among them, GYY4137 showed a BP-lowering effect in both CSE inhibition-induced pre-eclampsia and L-NAME-treated SHR [75,76]. Additionally, GYY4137 caused both antihypertensive and renoprotective effects in an Ang II-induced hypertensive model [59]. In addition to slow-releasing $\mathrm{H}_{2} \mathrm{~S}$ compounds, hybrids of $\mathrm{H}_{2} \mathrm{~S}$ and other drugs are receiving attention. Although $\mathrm{H}_{2} \mathrm{~S}$-releasing hybrids such as SG1002 ( $\mathrm{H}_{2} \mathrm{~S}-\mathrm{NO}$ hybrid) and ATB-346 $\left(\mathrm{H}_{2} \mathrm{~S}-\mathrm{NSAID}\right.$ hybrid) are now being demonstrated in clinical trials, there remains a need to better understand the underlying mechanisms for the treatment of a wide range of disorders, especially hypertension and kidney disease [77].

In contrast to the multitude of studies in adults, there are very few DOHaD studies on the role of $\mathrm{H}_{2} \mathrm{~S}$ donors in hypertension and developmental kidney disease. NaHS therapy between four and six weeks of age has been reported to prevent hypertension in adult SHRs [33]. Another report showed that renovascular hypertensive mother rats treated with $\mathrm{NaHS}$ can protect their offspring against hypertension [34]. However, none of the organic slow-releasing $\mathrm{H}_{2} \mathrm{~S}$ compounds and $\mathrm{H}_{2} \mathrm{~S}$-releasing hybrids have been examined in terms of their beneficial effects on programmed hypertension and kidney disease.

\subsection{Natural Plant-Derived Compounds}

Garlic-derived polysulfide compounds have drawn attention as natural precursors of $\mathrm{H}_{2} \mathrm{~S}$. A growing body of reports have shown that garlic-derived polysulfide compounds have the potential for ameliorating hypertension and associated morbidity [78,79]. Polysulfides in garlic may also influence the regulation of the NO signaling pathway, leading to NO-mediated vasodilation and reduction of BP [79]. Also, garlic-derived compounds provide renoprotection in several models of kidney disease, such as renal ischemia/reperfusion injury [80], acetaminophen-induced nephrotoxicity [81], and gentamicin-induced nephrotoxicity [82]. However, the reprogramming effects of these compounds on hypertension and kidney disease of developmental origins have not yet been examined.

\subsection{Others}

A number of currently used drugs have been reported to increase $\mathrm{H}_{2} \mathrm{~S}$ concentrations, such as ramipril, atorvastatin, amlodipine, vitamin $\mathrm{D}$, digoxin, aspirin, paracetamol, carvediol, testosterone, 17 $\beta$-estradiol, and metformin [60]. Despite progress made in recent years on pharmacotherapies in the $\mathrm{H}_{2} \mathrm{~S}$ field, very few studies have targeted their potential in reprogramming. With a better understanding on the interplay between the $\mathrm{H}_{2} \mathrm{~S}$ signaling pathway and other mechanisms underlying renal programming, the application of reprogramming strategies targeting the abovementioned mechanisms is feasible for early intervention.

For example, there is a growing body of evidence that AMPK activators possess therapeutic potential in treating hypertension and kidney disease [83,84]. Since AMPK is part of the nutrient-sensing signaling involved in renal programming, and AMPK is an important $\mathrm{H}_{2} \mathrm{~S}$ downstream signal [45], it would be interesting to see whether AMPK activators may be a useful 
reprogramming strategy to prevent developmental programming of hypertension and kidney disease. Given the fact that most available $\mathrm{H}_{2} \mathrm{~S}$-releasing drugs are still in preclinical experiments, targeting the $\mathrm{H}_{2} \mathrm{~S}$ downstream signal-related mechanisms would appear to be a practical approach for further clinical translation.

\section{Conclusions}

Advances in experimental research indicate that the $\mathrm{H}_{2} \mathrm{~S}$ signaling pathway may provide potential therapeutic targets for treating hypertension and kidney disease. Targeting the $\mathrm{H}_{2} \mathrm{~S}$ signaling pathway as a reprogramming strategy against hypertension and developmental kidney disease is a flourishing field and will become even more important in light of the growing epidemic of hypertension and kidney disease.

This review has provided an overview on the various reprogramming strategies that are relevant to the $\mathrm{H}_{2} \mathrm{~S}$ signaling pathway, including precursors for $\mathrm{H}_{2} \mathrm{~S}$ synthesis, $\mathrm{H}_{2} \mathrm{~S}$ donors, and natural plant-derived compounds. Also, reprogramming interventions may be achieved by targeting the $\mathrm{H}_{2} \mathrm{~S}$ downstream signal, which mediates particular mechanisms of renal programming. Although emerging evidence from animal studies supports $\mathrm{H}_{2} \mathrm{~S}$ as a reprogramming strategy for long-term protection against hypertension and developmental kidney disease, these results await further clinical translation.

Author Contributions: C.-N.H. contributed to concept generation, data interpretation, drafting of the manuscript, critical revision of the manuscript, and approval of the article; Y.-L.T. contributed to concept generation, data interpretation, critical revision of the manuscript, and approval of the article.

Funding:: This work was supported by the Grants CMRPG8F0251, CMRPG8G0671, and CMRPG8D0271 from Chang Gung Memorial Hospital, Kaohsiung, Taiwan.

Conflicts of Interest: The authors declare no conflict of interest.

\section{Abbreviations}

$\begin{array}{ll}\text { ACE } & \text { Angiotensin-converting enzyme } \\ \text { AMPK } & \text { Cyclic adenosine monophosphate (AMP)-activated protein kinase } \\ \text { AT1R } & \text { Angiotensin II type 1 receptor } \\ \text { CAT } & \text { Cysteine aminotransferase } \\ \text { CBS } & \text { Cystathionine } \beta \text {-synthase } \\ \text { CSE } & \text { Cystathionine } \gamma \text {-lyase } \\ \text { DAO } & \text { D-amino acid oxidase } \\ \text { DOHaD } & \text { Developmental origins of health and disease } \\ \text { L-NAME } & \mathrm{N}^{\mathrm{G}} \text {-nitro-L-arginine-methyl-ester } \\ \text { NAC } & \text { N-acetylcysteine } \\ \text { NaHS } & \text { Sodium hydrosulfide } \\ \text { NCC } & \text { Na }{ }^{+} / \text {Cl- cotransporter } \\ \text { NHE3 } & \text { Type } 3 \text { sodium hydrogen exchanger } \\ \text { NKCC2 } & \text { Na-K-2Cl cotransporter } \\ \text { PGC-1 } \alpha & \text { Peroxisome proliferator-activated receptor } \gamma \text { coactivator- } 1 \alpha \\ \text { PPAR } & \text { Peroxisome proliferator-activated receptor } \\ \text { RAS } & \text { Renin-angiotensin system } \\ \text { SHR } & \text { Spontaneously hypertensive rat } \\ \text { SIRT } & \text { Silent information regulator transcript } \\ \text { 3MST } & \text { 3-mercaptopyruvate sulphurtransferase } \\ & \end{array}$




\section{References}

1. Haugen, A.C.; Schug, T.T.; Collman, G.; Heindel, J.J. Evolution of DOHaD: The impact of environmental health sciences. J. Dev. Orig. Health Dis. 2015, 6, 55-64. [CrossRef] [PubMed]

2. Luyckx, V.A.; Bertram, J.F.; Brenner, B.M.; Fall, C.; Hoy, W.E.; Ozanne, S.E.; Vikse, B.E. Effect of fetal and child health on kidney development and long-term risk of hypertension and kidney disease. Lancet 2013, 382, 273-283. [CrossRef]

3. Chong, E.; Yosypiv, I.V. Developmental programming of hypertension and kidney disease. Int. J. Nephrol. 2012, 2012, 760580. [CrossRef] [PubMed]

4. Paixão, A.D.; Alexander, B.T. How the kidney is impacted by the perinatal maternal environment to develop hypertension. Biol. Reprod. 2013, 89, 144. [CrossRef] [PubMed]

5. Kett, M.M.; Denton, K.M. Renal programming: Cause for concern? Am. J. Physiol. Regul. Integr. Comp. Physiol. 2011, 300, R791-R803. [CrossRef] [PubMed]

6. Tain, Y.L.; Joles, J.A. Reprogramming: A preventive strategy in hypertension focusing on the kidney. Int. J. Mol. Sci. 2015, 17, 23. [CrossRef] [PubMed]

7. Kimura, H. The physiological role of hydrogen sulfide and beyond. Nitric Oxide 2014, 41, 4-10. [CrossRef] [PubMed]

8. Olas, B. Medical functions of hydrogen sulfide. Adv. Clin. Chem. 2016, 74, 195-210. [PubMed]

9. Feliers, D.; Lee, H.J.; Kasinath, B.S. Hydrogen sulfide in renal physiology and disease. Antioxid. Redox Signal. 2016, 25, 720-731. [CrossRef] [PubMed]

10. Shibuya, N.; Kimura, H. Production of hydrogen sulfide from d-cysteine and its therapeutic potential. Front. Endocrinol. 2013, 4, 87. [CrossRef] [PubMed]

11. Paul, B.D.; Snyder, S.H. $\mathrm{H}_{2} \mathrm{~S}$ signalling through protein sulfhydration and beyond. Nat. Rev. Mol. Cell Biol. 2012, 13, 499-507. [CrossRef] [PubMed]

12. Yan, H.; Du, J.; Tang, C. The possible role of hydrogen sulfide on the pathogenesis of spontaneous hypertension in rats. Biochem. Biophys. Res. Commun. 2004, 313, 22-27. [CrossRef] [PubMed]

13. Xiao, L.; Dong, J.H.; Jin, S.; Xue, H.M.; Guo, Q.; Teng, X.; Wu, Y.M. Hydrogen sulfide improves endothelial dysfunction via downregulating BMP4/COX-2 pathway in rats with hypertension. Oxid. Med. Cell Longev. 2016, 2016, 8128957. [CrossRef] [PubMed]

14. Zhong, G.; Chen, F.; Cheng, Y.; Tang, C.; Du, J. The role of hydrogen sulfide generation in the pathogenesis of hypertension in rats induced by inhibition of nitric oxide synthase. J. Hypertens. 2003, 21, 1879-1885. [CrossRef] [PubMed]

15. Huang, P.; Chen, S.; Wang, Y.; Liu, J.; Yao, Q.; Huang, Y.; Li, H.; Zhu, M.; Wang, S.; Li, L.; et al. Down-regulated CBS/H2S pathway is involved in high-salt-induced hypertension in Dahl rats. Nitric Oxide 2015, 46, 192-203. [CrossRef] [PubMed]

16. Yang, G.; Wu, L.; Jiang, B.; Yang, W.; Qi, J.; Cao, K.; Meng, Q.; Mustafa, A.K.; Mu, W.; Zhang, S.; et al. $\mathrm{H}_{2} \mathrm{~S}$ as a physiologic vasorelaxant: Hypertension in mice with deletion of cystathionine gamma-lyase. Science 2008, 322, 587-590. [CrossRef] [PubMed]

17. Ishii, I.; Akahoshi, N.; Yamada, H.; Nakano, S.; Izumi, T.; Suematsu, M. Cystathionine gamma-Lyase-deficient mice require dietary cysteine to protect against acute lethal myopathy and oxidative injury. J. Biol. Chem. 2010, 285, 26358-26368. [CrossRef] [PubMed]

18. Perna, A.F.; Ingrosso, D. Low hydrogen sulphide and chronic kidney disease: A dangerous liaison. Nephrol. Dial. Transp. 2012, 27, 486-493. [CrossRef] [PubMed]

19. Cao, X.; Bian, J.S. The Role of Hydrogen Sulfide in Renal System. Front. Pharmacol. 2016, 7, 385. [CrossRef] [PubMed]

20. Koning, A.M.; Frenay, A.R.; Leuvenink, H.G.; van Goor, H. Hydrogen sulfide in renal physiology, disease and transplantation-the smell of renal protection. Nitric Oxide 2015, 46, 37-49. [CrossRef] [PubMed]

21. Dugbartey, G.J. $\left.\mathrm{H}_{2}\right) \mathrm{S}$ as a possible therapeutic alternative for the treatment of hypertensive kidney injury. Nitric Oxide 2017, 64, 52-60. [CrossRef] [PubMed]

22. Van Goor, H.; van den Born, J.C.; Hillebrands, J.L.; Joles, J.A. Hydrogen sulfide in hypertension. Curr. Opin. Nephrol. Hypertens. 2016, 25, 107-113. [CrossRef] [PubMed] 
23. Tain, Y.L.; Chan, S.H.H.; Chan, J.Y.H. Biochemical basis for pharmacological intervention as a reprogramming strategy against hypertension and kidney disease of developmental origin. Biochem. Pharmacol. 2018. [CrossRef] [PubMed]

24. Te Riet, L.; van Esch, J.H.; Roks, A.J.; van den Meiracker, A.H.; Danser, A.H. Hypertension: Renin-angiotensin-aldosterone system alterations. Circ. Res. 2015, 116, 960-975. [CrossRef] [PubMed]

25. Yosypiv, I.V. Renin-angiotensin system in ureteric bud branching morphogenesis: Insights into the mechanisms. Pediatr. Nephrol. 2011, 26, 1499-1512. [CrossRef] [PubMed]

26. Bogdarina, I.; Welham, S.; King, P.J.; Burns, S.P.; Clark, A.J. Epigenetic modification of the renin-angiotensin system in the fetal programming of hypertension. Circ. Res. 2007, 100, 520-526. [CrossRef] [PubMed]

27. Chappell, M.C.; Marshall, A.C.; Alzayadneh, E.M.; Shaltout, H.A.; Diz, D.I. Update on the Angiotensin converting enzyme 2-Angiotensin (1-7)-MAS receptor axis: Fetal programing, sex differences, and intracellular pathways. Front. Endocrinol. 2014, 4, 201. [CrossRef] [PubMed]

28. Sherman, R.C.; Langley-Evans, S.C. Antihypertensive treatment in early postnatal life modulates prenatal dietary influences upon blood pressure in the rat. Clin. Sci. 2000, 98, 269-275. [CrossRef] [PubMed]

29. Manning, J.; Vehaskari, V.M. Postnatal modulation of prenatally programmed hypertension by dietary $\mathrm{Na}$ and ACE inhibition. Am. J. Physiol. Regul. Integr. Comp. Physiol. 2005, 288, R80-R84. [CrossRef] [PubMed]

30. Hsu, C.N.; Wu, K.L.; Lee, W.C.; Leu, S.; Chan, J.Y.; Tain, Y.L. Aliskiren administration during early postnatal life sex-specifically alleviates hypertension programmed by maternal high fructose consumption. Front. Physiol. 2016, 7, 299. [CrossRef] [PubMed]

31. Al-Magableh, M.R.; Kemp-Harper, B.K.; Hart, J.L. Hydrogen sulfide treatment reduces blood pressure and oxidative stress in angiotensin II-induced hypertensive mice. Hypertens. Res. 2015, 38, 13-20. [CrossRef] [PubMed]

32. Lu, M.; Liu, Y.H.; Goh, H.S.; Wang, J.J.; Yong, Q.C.; Wang, R.; Bian, J.S. Hydrogen sulfide inhibits plasma renin activity. J. Am. Soc. Nephrol. 2010, 21, 993-1002. [CrossRef] [PubMed]

33. Tain, Y.L.; Hsu, C.N.; Lu, P.C. Early short-term treatment with exogenous hydrogen sulfide postpones the transition from prehypertension to hypertension in spontaneously hypertensive rat. Clin. Exp. Hypertens. 2018, 40, 58-64. [CrossRef] [PubMed]

34. Guo, Q.; Feng, X.; Xue, H.; Teng, X.; Jin, S.; Duan, X.; Xiao, L.; Wu, Y. Maternal renovascular hypertensive rats treatment with hydrogen sulfide increased the methylation of AT1b gene in offspring. Am. J. Hypertens. 2017, 30, 1220-1227. [CrossRef] [PubMed]

35. Thompson, L.P.; Al-Hasan, Y. Impact of oxidative stress in fetal programming. J. Pregnancy 2012, 2012, 582748. [CrossRef] [PubMed]

36. Tain, Y.L.; Huang, L.T. Restoration of asymmetric dimethylarginine-nitric oxide balance to prevent the development of hypertension. Int. J. Mol. Sci. 2014, 15, 11773-11782. [CrossRef] [PubMed]

37. Predmore, B.L.; Lefer, D.J.; Gojon, G. Hydrogen sulfide in biochemistry and medicine. Antioxid. Redox Signal. 2012, 17, 119-140. [CrossRef] [PubMed]

38. Meng, G.; Ma, Y.; Xie, L.; Ferro, A.; Ji, Y. Emerging role of hydrogen sulfide in hypertension and related cardiovascular diseases. Br. J. Pharmacol. 2015, 172, 5501-5511. [CrossRef] [PubMed]

39. Jansson, T.; Powell, T.L. Role of placental nutrient sensing in developmental programming. Clin. Obstet. Gynecol. 2013, 56, 591-601. [CrossRef] [PubMed]

40. Tain, Y.L.; Hsu, C.N.; Chan, J.Y.; Huang, L.T. Renal transcriptome analysis of programmed hypertension induced by maternal nutritional insults. Int. J. Mol. Sci. 2015, 16, 17826-17837. [CrossRef] [PubMed]

41. Efeyan, A.; Comb, W.C.; Sabatini, D.M. Nutrient-sensing mechanisms and pathways. Nature 2015, 517, 302-310. [CrossRef] [PubMed]

42. Tain, Y.L.; Hsu, C.N.; Chan, J.Y. PPARs link early life nutritional insults to later programmed hypertension and metabolic syndrome. Int. J. Mol. Sci. 2015, 17, 20. [CrossRef] [PubMed]

43. Lee, J.; Giordano, S.; Zhang, J. Autophagy, mitochondria and oxidative stress: Cross-talk and redox signaling. Biochem. J. 2012, 441, 523-540. [CrossRef] [PubMed]

44. Tain, Y.L.; Hsu, C.N. Interplay between oxidative stress and nutrient sensing signaling in the developmental origins of cardiovascular disease. Int. J. Mol. Sci. 2017, 18, 841. [CrossRef] [PubMed]

45. Wang, M.; Tang, W.; Zhu, Y.Z. An update on AMPK in hydrogen sulfide pharmacology. Front. Pharmacol. 2017, 8, 810. [CrossRef] [PubMed] 
46. Ortiz, L.A.; Quan, A.; Weinberg, A.; Baum, M. Effect of prenatal dexamethasone on rat renal development. Kidney Int. 2001, 59, 1663-1669. [CrossRef] [PubMed]

47. Tain, Y.L.; Chen, C.C.; Sheen, J.M.; Yu, H.R.; Tiao, M.M.; Kuo, H.C.; Huang, L.T. Melatonin attenuates prenatal dexamethasone-induced blood pressure increase in a rat model. J. Am. Soc. Hypertens. 2014, 8, 216-226. [CrossRef] [PubMed]

48. Dagan, A.; Kwon, H.M.; Dwarakanath, V.; Baum, M. Effect of renal denervation on prenatal programming of hypertension and renal tubular transporter abundance. Am. J. Physiol.-Renal Physiol. 2008, 295, F29-F34. [CrossRef] [PubMed]

49. Tain, Y.L.; Lin, Y.J.; Sheen, J.M.; Yu, H.R.; Tiao, M.M.; Chen, C.C.; Tsai, C.C.; Huang, L.T.; Hsu, C.N. High fat diets sex-specifically affect the renal transcriptome and program obesity, kidney injury, and hypertension in the offspring. Nutrients 2017, 9, 357. [CrossRef] [PubMed]

50. Tain, Y.L.; Lin, Y.J.; Chan, J.Y.H.; Lee, C.T.; Hsu, CN. Maternal melatonin or agomelatine therapy prevents programmed hypertension in male offspring of mother exposed to continuous light. Biol. Reprod. 2017, 97, 636-643. [CrossRef] [PubMed]

51. Tain, Y.L.; Lee, W.C.; Leu, S.; Wu, K.; Chan, J. High salt exacerbates programmed hypertension in maternal fructose-fed male offspring. Nutr. Metab. Cardiovasc. Dis. 2015, 25, 1146-1151. [CrossRef] [PubMed]

52. Xia, M.; Chen, L.; Muh, R.W.; Li, P.L.; Li, N. Production and actions of hydrogen sulfide, a novel gaseous bioactive substance, in the kidneys. J. Pharmacol. Exp. Ther. 2009, 329, 1056-1062. [CrossRef] [PubMed]

53. Zhang, J.; Chen, S.; Liu, H.; Zhang, B.; Zhao, Y.; Ma, K.; Zhao, D.; Wang, Q.; Ma, H.; Zhang, Z. Hydrogen sulfide prevents hydrogen peroxide-induced activation of epithelial sodium channel through a PTEN/PI(3,4,5)P3 dependent pathway. PLoS ONE 2013, 8, e64304. [CrossRef] [PubMed]

54. Bianco-Miotto, T.; Craig, J.M.; Gasser, Y.P.; van Dijk, S.J.; Ozanne, S.E. Epigenetics and DOHaD: From basics to birth and beyond. J. Dev. Orig. Health Dis. 2017, 8, 513-519. [CrossRef] [PubMed]

55. Ly, A.; Ishiguro, L.; Kim, D.; Im, D.; Kim, S.E.; Sohn, K.J.; Croxford, R.; Kim, Y.I. Maternal folic acid supplementation modulates DNA methylation and gene expression in the rat offspring in a gestation period-dependent and organ-specific manner. J. Nutr. Biochem. 2016, 33, 103-110. [CrossRef] [PubMed]

56. Sene Lde, B.; Mesquita, F.F.; de Moraes, L.N.; Santos, D.C.; Carvalho, R.; Gontijo, J.A.; Boer, P.A. Involvement of renal corpuscle microRNA expression on epithelial-to-mesenchymal transition in maternal low protein diet in adult programmed rats. PLoS ONE 2013, 8, e71310. [CrossRef] [PubMed]

57. Tain, Y.L.; Chan, J.Y.; Hsu, C.N. Maternal fructose intake affects transcriptome changes and programmed hypertension in offspring in later life. Nutrients 2016, 8, 757. [CrossRef] [PubMed]

58. Leucker, T.M.; Nomura, Y.; Kim, J.H.; Bhatta, A.; Wang, V.; Wecker, A.; Jandu, S.; Santhanam, L.; Berkowitz, D.; Romer, L.; et al. Cystathionine $\gamma$-lyase protects vascular endothelium: A role for inhibition of histone deacetylase 6. Am. J. Physiol. Heart Circ. Physiol. 2017, 31, H711-H720. [CrossRef] [PubMed]

59. Weber, G.J.; Pushpakumar, S.B.; Sen, U. Hydrogen sulfide alleviates hypertensive kidney dysfunction through an epigenetic mechanism. Am. J. Physiol. Heart Circ. Physiol. 2017, 312, H874-H885. [CrossRef] [PubMed]

60. Bełtowski, J. Hydrogen sulfide in pharmacology and medicine-An update. Pharmacol. Rep. 2015, 67, 647-658. [CrossRef] [PubMed]

61. Guo, W.; Cheng, Z.Y.; Zhu, Y.Z. Hydrogen sulfide and translational medicine. Acta Pharmacol. Sin. 2013, 34, 1284-1291. [CrossRef] [PubMed]

62. Hsu, C.N.; Lin, Y.J.; Lu, P.C.; Tain, Y.L. Early supplementation of D-cysteine or L-cysteine prevents hypertension and kidney damage in spontaneously hypertensive rats exposed to high-salt intake. Mol. Nutr. Food Res. 2018, 62, 2. [CrossRef] [PubMed]

63. Fan, N.C.; Tsai, C.M.; Hsu, C.N.; Huang, L.T.; Tain, Y.L. N-acetylcysteine prevents hypertension via regulation of the ADMA-DDAH pathway in young spontaneously hypertensive rats. Biomed. Res. Int. 2013, 2013, 696317. [CrossRef] [PubMed]

64. Tai, I.H.; Sheen, J.M.; Lin, Y.J.; Yu, H.R.; Tiao, M.M.; Chen, C.C.; Huang, L.T.; Tain, Y.L. Maternal $\mathrm{N}$-acetylcysteine therapy regulates hydrogen sulfide-generating pathway and prevents programmed hypertension in male offspring exposed to prenatal dexamethasone and postnatal high-fat diet. Nitric Oxide 2016, 53, 6-12. [CrossRef] [PubMed]

65. Tain, Y.L.; Hsu, C.N.; Lee, C.Y.; Lin, Y.J.; Tsai, C.C. N-Acetylcysteine prevents programmed hypertension in male rat offspring born to suramin-treated mothers. Biol. Reprod. 2016, 95, 8. [CrossRef] [PubMed] 
66. Tain, Y.L.; Lee, C.T.; Chan, J.Y.; Hsu, C.N. Maternal melatonin or N-acetylcysteine therapy regulates hydrogen sulfide-generating pathway and renal transcriptome to prevent prenatal N(G)-Nitro-L-arginine-methyl ester (L-NAME)-induced fetal programming of hypertension in adult male offspring. Am. J. Obstet. Gynecol. 2016, 215, 636.e1-e36.e72. [CrossRef] [PubMed]

67. Xiao, D.; Huang, D.X.; Li, Y.; Dasgupta, C.; Wang, L.; Zhang, L. Antenatal antioxidant prevents nicotine-mediated hypertensive response in rat adult offspring. Biol. Reprod. 2015, 93, 66. [CrossRef] [PubMed]

68. Vasdev, S.; Singal, P.; Gill, V. The antihypertensive effect of cysteine. Int. J. Angiol. 2009, 18, 7-21. [CrossRef] [PubMed]

69. Khaledifar, A.; Mobasheri, M.; Kheiri, S.; Zamani, Z. Comparison of N-acetylcysteine and angiotensin converting enzyme inhibitors in blood pressure regulation in hypertensive patients. ARYA Atheroscler. 2015, 11, 5-13. [PubMed]

70. Friedman, M.; Levin, C.E. Nutritional and medicinal aspects of D-amino acids. Amino Acids 2012, 42, 1553-1582. [CrossRef] [PubMed]

71. Shibuya, N.; Koike, S.; Tanaka, M.; Ishigami-Yuasa, M.; Kimura, Y.; Ogasawara, Y.; Fukui, K.; Nagahara, N.; Kimura, H. A novel pathway for the production of hydrogen sulfide from D-cysteine in mammalian cells. Nat. Commun. 2013, 4, 1366. [CrossRef] [PubMed]

72. Ahmad, F.U.; Sattar, M.A.; Rathore, H.A.; Tan, Y.C.; Akhtar, S.; Jin, O.H.; Pei, Y.P.; Abdullah, N.A.; Johns, E.J. Hydrogen sulphide and tempol treatments improve the blood pressure and renal excretory responses in spontaneously hypertensive rats. Ren. Fail. 2014, 36, 598-605. [CrossRef] [PubMed]

73. Kimura, H. Hydrogen sulfide and polysulfides as biological mediators. Molecules 2014, 19, 16146-16157. [CrossRef] [PubMed]

74. Li, L.; Whiteman, M.; Guan, Y.Y.; Neo, K.L.; Cheng, Y.; Lee, S.W.; Zhao, Y.; Baskar, R.; Tan, C.H.; Moore, P.K. Characterization of a novel, water-soluble hydrogen sulfide-releasing molecule (GYY4137): New insights into the biology of hydrogen sulfide. Circulation 2008, 117, 2351-2360. [CrossRef] [PubMed]

75. Wang, K.; Ahmad, S.; Cai, M.; Rennie, J.; Fujisawa, T.; Crispi, F.; Baily, J.; Miller, M.R.; Cudmore, M.; Hadoke, P.W.; et al. Dysregulation of hydrogen sulfide producing enzyme cystathionine $\gamma$-lyase contributes to maternal hypertension and placental abnormalities in preeclampsia. Circulation 2013, 127, $2514-2622$. [CrossRef] [PubMed]

76. Sharma, D.K.; Manral, A.; Saini, V.; Singh, A.; Srinivasan, B.P.; Tiwari, M. Novel diallyldisulfide analogs ameliorate cardiovascular remodeling in rats with L-NAME-induced hypertension. Eur. J. Pharmacol. 2012, 691, 198-208. [CrossRef] [PubMed]

77. Wallace, J.L.; Vaughan, D.; Dicay, M.; MacNaughton, W.K.; de Nucci, G. Hydrogen sulfide-releasing therapeutics: Translation to the clinic. Antioxid. Redox Signal. 2017. [CrossRef] [PubMed]

78. Shouk, R.; Abdou, A.; Shetty, K.; Sarkar, D.; Eid, A.H. Mechanisms underlying the antihypertensive effects of garlic bioactives. Nutr. Res. 2014, 34, 106-115. [CrossRef] [PubMed]

79. Ried, K.; Fakler, P. Potential of garlic (Allium sativum) in lowering high blood pressure: Mechanisms of action and clinical relevance. Integr. Blood Press. Control 2014, 7, 71-82. [CrossRef] [PubMed]

80. Sener, G.; Sakarcan, A.; Yegen, B.C. Role of garlic in the prevention of ischemia-reperfusion injury. Mol. Nutr. Food Res. 2007, 51, 1345-1352. [CrossRef] [PubMed]

81. Ko, J.W.; Shin, J.Y.; Kim, J.W.; Park, S.H.; Shin, N.R.; Lee, I.C.; Shin, I.S.; Moon, C.; Kim, S.H.; Kim, H.; et al. Protective effects of diallyl disulfide against acetaminophen-induced nephrotoxicity: A possible role of CYP2E1 and NF-kB. Food Chem. Toxicol. 2017, 102, 156-165. [CrossRef] [PubMed]

82. Pedraza-Chaverrí, J.; Maldonado, P.D.; Barrera, D.; Cerón, A.; Medina-Campos, O.N.; Hernández-Pando, R. Protective effect of diallyl sulfide on oxidative stress and nephrotoxicity induced by gentamicin in rats. Mol. Cell Biochem. 2003, 254, 125-130. [CrossRef] [PubMed] 
83. Xu, Q.; Si, L.Y. Protective effects of AMP-activated protein kinase in the cardiovascular system. J. Cell Mol. Med. 2010, 14, 2604-2613. [CrossRef] [PubMed]

84. Rajani, R.; Pastor-Soler, N.M.; Hallows, K.R. Role of AMP-activated protein kinase in kidney tubular transport, metabolism, and disease. Curr. Opin. Nephrol. Hypertens. 2017, 26, 375-383. [CrossRef] [PubMed] 